\title{
Energy production for environmental issues in Turkey
}

\author{
Ibrahim Yuksel ${ }^{1, *}$, Hasan Arman ${ }^{2}$, and Ibrahim Halil Demirel ${ }^{3}$ \\ ${ }^{1}$ Yildiz Technical University, Faculty of Civil Engineering, Department of Civil Engineering, \\ Hydraulics Division, 34220 Davutpasa, Istanbul, Turkey \\ ${ }^{2}$ United Arab Emirates University, College of Science, Geology Dep., P.O. 15551, Al-Ain, UAE \\ ${ }^{3}$ Yildiz Technical University, Civil Engineering Ph.D. Student, 34220, Istanbul, Turkey
}

\begin{abstract}
Due to the diversification efforts of energy sources, use of natural gas that was newly introduced into Turkish economy, has been growing rapidly. Turkey has large reserves of coal, particularly of lignite. The proven lignite reserves are 8.0 billion tons. The estimated total possible reserves are 30 billion tons. Turkey, with its young population and growing energy demand per person, its fast growing urbanization, and its economic development, has been one of the fast growing power markets of the world for the last two decades. It is expected that the demand for electric energy in Turkey will be 580 billion $\mathrm{kWh}$ by the year 2020 . Turkey's electric energy demand is growing about $6-8 \%$ yearly due to fast economic growing. This paper deals with energy demand and consumption for environmental issues in Turkey.
\end{abstract}

\section{Introduction}

Turkey has dynamic economic development and rapid population growth. Turkey's population of about 80 million is growing. Along with the economic growth and population increase, significant increases were observed both in primary energy (primary energy sources include lignite, hard coal, oil, natural gas, hydroelectricity, geothermal, wood, animal and plant wastes, solar and wind) and electricity consumption during the 8th Plan period.

Over the last few decades, the numbers of Turkish citizens live in the eastern part of country have migrated to the western part of the country. This caused some problems in the energy utilization and environmental pollution in the western regions in Turkey. In this case, in the coming decades, global environmental issues could significantly affect patterns of energy use in Turkey. As in the world, hydropower has a great role in the global environmental issues such as environmental and air pollutions in Turkey.

* Corresponding author: yukseli2000@yahoo.com or iyuksel@yildiz.edu.tr 
Affordable energy services are among the essential ingredients of economic development, including eradication of extreme poverty as called for in the United Nations Millennium Development Goal (DGs). Modern energy services-mainly provided by liquid and gaseous fuels, as well as electricity-are essential. Convenient, affordable energy is also important for improving health and education, and for reducing the human labour required to cook and meet other basic needs [1-3].

Renewable energy projects developed in scores of developing countries-many with international donor assistance-have demonstrated that renewable energy can contribute to poverty alleviation directly by providing the energy needed for creating business and jobs, turning locally available resources into productive economic assets [2].

However, developing the remaining hydropower potential offers many challenges and pressures from some environmental action groups over its impact has tended to increase over time. Hydropower throughout the world provides $17 \%$ of electricity from installed capacity in Turkey. The contribution of hydropower, especially small hydropower (SHP) to the worldwide electrical capacity is more of a similar scale to the other renewable energy sources (1-2\% of total capacity), amounting to about $47 \mathrm{GW}(53 \%)$ of this capacity is in developing countries [2, 3].

In the coming decades, global environmental issues could significantly affect patterns of energy use in Turkey. As in the world, hydropower has a great role in the global environmental issues such as environmental and air pollutions in Turkey. This paper deals with the role of hydropower in energy utilization and environmental pollution in Turkey [3].

A suitable environment will be established, with legislative regulations if necessary, in order for the private sector to fill the gap that will arise as a result of the withdrawal of the state from the sector, in a timely manner and to expedite the start of the new production investments in line with supply and demand projections. Thus, emphasis will be given to privatization of the existing facilities in order to prevent the burden of new investments on the state. The state will be adequately equipped in a way to closely monitor the supply security within the framework of its regulatory and supervisory role and to take measures [4].

\section{Hydropower for energy policies and environmental issues}

Hydropower is available in a broad range of Project scales and types. Projects can be designed to suit particular needs and specific site conditions. As hydropower does not consume or pollute the water it uses to generate power, it leaves this vital resource available for other uses. At the same time, the revenues generated through electricity sales can finance other infrastructure essential for human welfare. This can include drinking water supply systems, irrigation schemes for food production, infrastructures enhancing navigation, recreational facilities and ecotourism.

Hydropower has very few greenhouse gas emissions compared with other large-scale energy options. Table 1 shows the comparison of energy amortization time and emissions of various energy technologies [1]. In addition, by storing water during rainy seasons and releasing it during dry ones, dams and reservoirs can help control water during floods and droughts. These essential functions protect human lives and other assets. This will be increasingly important in the context of global warming, which implies an expected rising variability in precipitation frequency and intensity. On the other hand, hydropower projects do not export impacts such as acid rain or atmospheric pollution. Environmental impacts are limited to changes in the watershed in which the dam is located. When well-managed, these changes can sometimes result in enhancements, and other impacts can be avoided, mitigated. Hydropower can contribute to mitigating the widespread potential human impacts 
of climate change [5-7]. There is no single solution to the world's quest for more, cleaner energy and effective water management. Energy and water for sustainable development depend not only on supply choices, but also on how these choices are implemented. It requires the creation of a level playing field among available energy options and global water governance involving all stakeholders in a participatory decision-making process. In adopting their own sustainability guidelines, the members of the

International Hydropower Association are committed to developing and operating their projects, in collaboration with all stakeholders, in a way that is environmentally friendly, socially responsible and economically efficient so that hydropower projects can make

a major contribution to achieving sustainable energy and resource development [6, 7]. Hydropower energy is a renewable, sustainable and clean energy in the other alternative energy sources. Moreover, it does not deprive future generations in terms of raw materials, or burdening them with pollutants or waste.

Hydroelectric power plants utilize the basic national and renewable resource of the country. Although the initial investment cost of hydropower seems relatively high, the projects have the lowest production costs and do not depend on foreign capital and support, when considering environmental pollution and long-term economic evaluation $[3,6,8]$.

Main aim of the energy policies is to meet the energy needs of increasing population and growing economy in a continuous, qualified and secure manner through primarily private sector investments in a competitive and transparent free market environment. In this context, it is the main target to supply the required energy timely, uninterrupted and at minimum costs while making energy supply planning [9].

A suitable environment will be established, with legislative regulations if necessary, in order for the private sector to fill the gap that will arise as a result of the withdrawal of the state from the sector, in a timely manner and to expedite the start of the new production investments in line with supply and demand projections [10]. Thus, emphasis will be given to privatization of the existing facilities in order to prevent the burden of new investments on the state. The state will be adequately equipped in a way to closely monitor the supply security within the framework of its regulatory and supervisory role and to take measures [11].

It is fundamental to complete the projects, in particular the hydroelectricity power plant projects, covered by the public investment program with the lowest costs and in the fastest manner. For this reason, emphasis will be given to ensure that investment costs reflect the true cost, cross financing among sectors are avoided and cost increases that could arise as a result of delays in projects are prevented.

On the other hand, in order to create a healthy diversification in electricity supply, nuclear energy will also be included among electricity production resources. Before the construction of a nuclear power plant, detailed plans and programs on storage, elimination of wastes and informing the public will be prepared by considering maximum harmony with the free market $[3,6]$. 
Table 1. The comparison of energy amortization time and emissions of various energy technologies.

\begin{tabular}{|c|c|c|c|c|}
\hline Technology & $\begin{array}{c}\text { Energy pay } \\
\text { back } \\
\text { time in months }\end{array}$ & $\begin{array}{c}\text { SO } \text { emission } \\
\text { in } \mathbf{~ k g / G W h}\end{array}$ & $\begin{array}{c}\mathbf{N O}_{2} \\
\text { emission } \\
\text { in } \mathbf{~ k g / G W h}\end{array}$ & $\begin{array}{c}\mathbf{C O}_{2} \text { in } \\
\text { Ton/GWh }\end{array}$ \\
\hline Coal fired & $1.0-1.1$ & $630-1370$ & $630-1560$ & $830-920$ \\
\hline Gas (CCGT) & 0.4 & $45-140$ & $650-810$ & $370-420$ \\
\hline Large-hydro & $5-6$ & $18-21$ & $34-40$ & $7-8$ \\
\hline Micro hydro & $9-11$ & $38-46$ & $71-86$ & $16-20$ \\
\hline Small hydro & $8-9$ & $24-29$ & $46-56$ & $10-12$ \\
\hline \multicolumn{5}{|c|}{ Wind turbine } \\
\hline $4.5 \mathrm{~m} / \mathrm{s}$ & $6-20$ & $18-32$ & $26-43$ & $19-34$ \\
\hline $5.5 \mathrm{~m} / \mathrm{s}$ & $4-13$ & $13-20$ & $18-27$ & $13-22$ \\
\hline $6.5 \mathrm{~m} / \mathrm{s}$ & $2-8$ & $10-16$ & $14-22$ & $10-17$ \\
\hline \multicolumn{5}{|c|}{ Photovoltaic } \\
\hline Mono-crystalline & $72-93$ & $230-295$ & $270-340$ & $200-260$ \\
\hline Multi-crystalline & $58-74$ & $260-330$ & $250-310$ & $190-250$ \\
\hline Amorphous & $51-66$ & $135-175$ & $160-200$ & $170-220$ \\
\hline
\end{tabular}

Source: [1].

\section{Hydropower for renewable, sustainable and clean energy}

As a contributor of air pollution and deforestation, the share of biomass in the renewable energy share is expected to decrease with the expansion of other renewable energy sources [12]. Table 2 shows renewable energy supply and projections for future in Turkey, respectively $[13,14]$.

The aim of the Renewable Energy Program is to increase privately-owned and operated power generation from renewable sources within a market-based framework, which is being implemented in accordance with the Electricity Market Law and the Electricity Sector Reform Strategy [15]. This program will assist the Directorate of the Ministry of Energy and Natural Resources (MENR) in the preparation of a renewable energy law, as well as to define the required changes and modifications related to legislation such as the Electricity Market Law to better accommodate greater private sector involvement $[12,15]$.

Turkey has aimed at increasing domestic production by public, private and foreign utilities, at increasing efficiency by rehabilitation of existing plants and acceleration of existing construction programs. On the other hand, there are 436 sites available for hydroelectric plant construction, distributed on 26 main river zones.

At present, the average hydroelectric capacity in Turkey is $45 \mathrm{TWh} / \mathrm{yr}$ which corresponds to only $36 \%$ of the total economically feasible potential of the country. Up to 2020, it is expected that about 502 new hydropower plants will be constructed to make use of the full available potential [6,16-19].

The distribution of hydroelectric power potential in Turkey is as shown in Table 3. By 2020 , it is expected that the total hydro installed capacity will be almost 36,000 MW. Thus, within this framework, it is also expected that the GAP (Southeastern Anatolian Project) will comprise 22 dams and 19 hydroelectric plants and a total generation of about

$27 \mathrm{TWh} / \mathrm{yr}$, and the irrigation of an area of 1,785,050 ha will be realized. The GAP is an integrated, multi-sectorial development project, and covers many sectors such as agriculture, industry, transportation, water sports, etc. [20, 21]. 
Table 2. Renewable energy supply in Turkey.

\begin{tabular}{|c|c|c|c|c|c|}
\hline Renewable energy sources & $\mathbf{2 0 0 0}$ & $\mathbf{2 0 0 5}$ & $\mathbf{2 0 1 0}$ & $\mathbf{2 0 1 5}$ & $\mathbf{2 0 2 0}$ \\
\hline \multicolumn{7}{|c|}{ Primary energy supply } \\
\hline Hydropower (ktoe) & 2656 & 4067 & 4903 & 7060 & 9419 \\
\hline Geothermal, solar and wind (ktoe) & 978 & 1683 & 2896 & 4242 & 6397 \\
\hline Biomass and waste (ktoe) & 6457 & 5325 & 4416 & 4001 & 3925 \\
\hline Renewable energy production (ktoe) & 10091 & 11074 & 12215 & 15303 & 19741 \\
\hline Share of total domestic production (\%) & 38 & 48 & 33 & 29 & 30 \\
\hline Share of TPES (\%) & 12 & 12 & 10 & 9 & 9 \\
\hline \multicolumn{7}{|c|}{ Generation } \\
\hline Hydropower (GWh) & 30879 & 47287 & 57009 & 82095 & 109524 \\
\hline Geothermal, solar and wind (GWh) & 109 & 490 & 5274 & 7020 & 8766 \\
\hline Renewable energy generation (GWh) & 30988 & 47777 & 62283 & 89115 & 118290 \\
\hline Share of total generation (\%) & 25 & 29 & 26 & 25 & 25 \\
\hline \multicolumn{7}{|c|}{ Total final consumption } \\
\hline Geothermal, solar and wind (ktoe) & 910 & 1385 & 2145 & 3341 & 5346 \\
\hline Biomass and waste (ktoe) & 6457 & 5325 & 4416 & 4001 & 3925 \\
\hline Renewable total consumption (ktoe) & 7367 & 6710 & 6561 & 7342 & 9271 \\
\hline Share of total final consumption (\%) & 12 & 10 & 7 & 6 & 6 \\
\hline
\end{tabular}

Source: $[13,14]$.

Table 3. Present and potential of hydroelectric power in Turkey.

\begin{tabular}{|c|c|c|c|c|}
\hline Present hydropower plants & $\begin{array}{c}\text { Number } \\
\text { of } \\
\text { Power } \\
\text { Stations }\end{array}$ & $\begin{array}{c}\text { Total } \\
\text { installed } \\
\text { Capacity } \\
\text { (MW) }\end{array}$ & $\begin{array}{c}\text { Proven } \\
\text { Production } \\
\text { (GWh/year) }\end{array}$ & $\begin{array}{c}\text { Total Annual } \\
\text { Production } \\
\text { (GWh/year) }\end{array}$ \\
\hline In production > 10 MW & 74 & 193 & 287 & 722 \\
\hline In production <10 MW & 68 & 12,595 & 33,273 & 45,208 \\
\hline Under construction > 10 MW & 8 & 45 & 151 & 228 \\
\hline Under construction <10 MW & 32 & 3,152 & 6,207 & 10,290 \\
\hline Present total & 182 & 15,985 & 39,918 & 56,448 \\
\hline Future Possible Potential & & & & \\
\hline$>5$ MW & 164 & 366 & 571 & 1,848 \\
\hline $5-10 \mathrm{MW}$ & 82 & 610 & 897 & 2,587 \\
\hline $10-50 \mathrm{MW}$ & 187 & 4,727 & 9,234 & 18,959 \\
\hline $50-100 \mathrm{MW}$ & 51 & 3,692 & 7,734 & 13,001 \\
\hline $100-250 \mathrm{MW}$ & 37 & 5,815 & 11,824 & 19,308 \\
\hline $240-500 \mathrm{MW}$ & 10 & 3,250 & 5,620 & 10,688 \\
\hline $500-1000 \mathrm{MW}$ & 2 & 1,053 & 2,054 & 3,173 \\
\hline $1000<\mathrm{MW}$ & 1 & 1,200 & 2,459 & 3,833 \\
\hline Future Total & 534 & 20,713 & 40,393 & 73,398 \\
\hline TOTAL & 716 & 36,698 & 80,311 & 129,846 \\
\hline
\end{tabular}

Source: [16]. 


\section{Air pollution, climate change and $\mathrm{CO}_{2}$ factors for renewable energy in Turkey}

Since the Kyoto Protocol in December 1997, at the Third Conference of the Parties to the United Framework Convention on Climate Change (UNFCC), international attention is growing toward a consensus in favor of reducing carbon emission to mitigate climate change [10].

The leading options for achieving cost-efficiency in carbon emission reductions address the design issue of how to implement an emission cap-and-trade system in Turkey. We therefore examine the design of alternatives permits trading programs to address carbon emission related energy-consumption. In this context, tradable emission permits would entitle holders to emit up to a specified level of carbon emissions. By issuing a fixed number of allowances less than business-as-usual current emissions, Turkey could reduce its national $\mathrm{CO}_{2}$ emissions to meet internationally targets $[4,11,22]$.

Emissions of $\mathrm{CO}_{2}, \mathrm{SO}_{2}$ and $\mathrm{NO}_{\mathrm{x}}$ have increased over the 1980s (Table 4) both in absolute terms and relative to GDP. Turkey is the only OECD country were the intensity of emissions of $\mathrm{NO}_{2}$ rose in this period, while it was one of only two countries that experienced an increase in $\mathrm{SO}_{2}$ emission intensity.

By the late 1990s, emissions of $\mathrm{SO}_{2}$ in relation to GDP were double the OECD average, reflecting the heavy share of high-sulfur lignite in power generation and poor quality liquid fuels. Since the end of the 1990s, natural gas usage has been rising rapidly and this has helped concentrations of $\mathrm{SO}_{2}$ to decline markedly in some of the major urban areas, such as Ankara, Izmir and Istanbul, but they still remain at levels that are double those found on the average in OECD metropolitan areas.

Concentrations in the rest of the country, as measured by a simple average of all monitoring stations, are some $75 \%$ higher than in the three metropolitan areas. In addition there has been little downward movement in the estimated concentrations of lead in the air, but levels in Turkey are low compared to those found in a number of European countries [10].

Table 4. Total greenhouse gas emissions in Turkey.

\begin{tabular}{|c|c|c|c|c|}
\hline Year & $\begin{array}{c}\mathrm{CO}_{2} \\
\text { (Mt/year) }\end{array}$ & $\begin{array}{c}\text { NOx } \\
\text { (kt/year) }\end{array}$ & $\begin{array}{c}\mathrm{SO}_{2} \\
\text { (kt/year) }\end{array}$ & $\begin{array}{c}\mathrm{CH}_{4} \\
\text { (kt/year) }\end{array}$ \\
\hline 1980 & 73.3 & 372 & 17.5 & 128 \\
\hline 1990 & 133 & 656 & 31 & 150 \\
\hline 1995 & 162 & 785 & 33 & 140 \\
\hline 2000 & 254 & 1166 & 45.7 & 190 \\
\hline 2010 & 460 & 2046 & 79.4 & 216 \\
\hline
\end{tabular}

Mt: Million tons; kt: kilo tons. Source: [10].

\section{Conclusions}

Energy projects, in particular the hydroelectricity power plant projects, covered by the public investment program with the lowest costs and in the fastest manner. For this reason, emphasis will be given to ensure that investment costs reflect the true cost, cross financing among sectors are avoided and cost increases that could arise as a result of delays in projects are prevented.

On the other hand, in order to create a healthy diversification in electricity supply, nuclear energy will also be included among electricity production resources. Before the construction of a nuclear power plant, detailed plans and programs on storage, elimination 
of wastes and informing the public will be prepared by considering maximum harmony with the free market

As a large hydro energy project the Southeastern Anatolian Project (GAP) will also integrate, multi-sectorial development project, and covers many sectors such as agriculture, industry, transportation and water sports.

Renewable energy supply in Turkey is dominated by hydropower and biomass, but environmental and scarcity-of-supply concerns have led to a decline in biomass use, mainly for residential heating. As a contributor of air pollution and deforestation, the share of biomass in the renewable energy share is expected to decrease with the expansion of other renewable energy sources such as solar and wind.

In view of the low operational costs of hydropower, related to not having any fuel expense, hydro plants can easily fit load demand, while having a long economic life and low environmental impacts compared with alternative energy resources.

\section{Acknowledgments}

This study was supported by Yildiz Technical University, Scientific Research Coordinator, Istanbul, Turkey. Project ID: 1897, Project Number: 2016-05-01-KAP01.

\section{References}

1. UNDP, United Nations Development program, World Energy Assessment Report, New York: United Nations, 2000

2. I. Yuksel, J. En. So., Part B: Eco., Plan., and Pol. 2, 2, 113-121 (2007)

3. I. Yuksel, A. Dorum, J. En. So., Part A: Rec. Utiliz. and Env. Eff. 33, 13, 1221-1229, (2011).

4. I. Yuksel, J. of E. S., Part A: R., Ut., and En. Ef. 31, 20, 1915-1925 (2009)

5. WEC, World Energy Council, Survey of Energy Resources, www.worldenergy.org (2000)

6. I. Yuksel, J. of R. and Sust. En. Re. 12, 6, 1622 - 1640 (2008)

7. IHA, International Hydropower Association, The Role of Hydropower in Sustainable Development, IHA White Paper, 1-140 (2003)

8. O. Paish, Re. and Sust. En. Rev. 6, 537 - 556 (2002)

9. DPT, State Planning Organization. Ninth Development plan 2007-2013, (2006)

10. MEF, Ministry of Environment and Forestry. First national Communication of Turkey on Climate Change, 60-150 (2007)

11. MENR, Ministry of Energy and Natural Resources. Energy Statistics in Turkey, www.enerji.gov.tr (2007)

12. K. Kaygusuz, A. Sar1, En. So., Part B 1, 23-35 (2006)

13. IEA, International Energy Agency. Energy policies of IEA countries: Turkey 2005 review, Paris: OECD/IEA, (2005)

14. MENR, Ministry of Energy and Natural Resources. Energy Statistics in Turkey. http://www.enerji.gov.tr (2009)

15. TEIAS, Turkish Electricity Transmission Corporation. Annual Report (2006)

16. DSI, State Hydraulic Works, Hydropower potential in Turkey (2007) 
17. R. Ozturk, O. Kincay. En. So. 26, 1141-1156 (2004)

18. O. Yuksek, M.I. Kömürcü, I. Yüksel, K. Kaygusuz, En. Po. 34, 3093-3103 (2006)

19. K. Kaygusuz, O. Yüksek, A. Sarı, En. So., Part B 2, 19-29 (2007)

20.GAP, Southeastern Anatolia Project. Energy production in GAP region, www.gap.gov.tr, (2006)

21. O. Yuksek, K. Kaygusuz, En. So., Part B 1, 279-290 (2006)

22. K. Kaygusuz, Cl. 35, 539-547 (2007) 